\title{
Profit from Noise Trading: An Opinion Survey on Bangladeshi Stock Market
}

\author{
Md. Ashraful Islam Khan
}

Associate Professor, Department of Population Science and Human Resource Development,Rajshahi University, Rajshahi, BANGLADESH

*Corresponding Contact:

Email: khan75ru@gmail.com

\begin{abstract}
Stock market plays the crucial role to move funds from the surplus units to the deficit units, therefore, it accelerate the economic development of a country. Noise trading is one of the important issues that influence the stock market volatility dynamics. Noise traders are very sensitive in having well or bad news rather use standard data/stock index for decision to buy or sell share. This sensitivity makes market more volatile. The aim of this study is to collect opinions from the market practitioners on their thinking about noise trading and profit from stock market.
\end{abstract}

Keywords:Noise Trading, Noise trader, Market Microstructure Noise, Volatility

$5 / 11 / 2016$

Source of Support: Nil,No Conflict of Interest: Declared

How to Cite: Khan MA. 2016. Profit from Noise Trading: An Opinion Survey on Bangladeshi Stock Market $A B C$

Journal of Advanced Research, 5, 53-60.

This article is is licensed under a Creative Commons Attribution-NonCommercial 4.0 International License.

Attribution-NonCommercial (CC BY-NC) license lets others remix, tweak, and build upon work non-commercially, and

although the new works must also acknowledge \& be non-commercial.

\section{INTRODUCTION}

Noise means certain information or activity that puzzles or misrepresents genuine underlying trends. Albert Kyle (1985) and Fischer Black (1986) introduced the term "Noise trader" to represent a stock trader who lacks access to inside information and makes irrational investment decisions (DeLong et al., 1990) while noise trading is one of those market forces that deviate equity prices from their true values.

Philosophy of most of the noise traders is that they are making sound investment decisions compared to other investors as they follow market noise. The noise traders often make decision not based on any fundamental data, they usually over react to good or bad news and take quick decision in favor of a particular noise, and hence, they may make poor decisions.

The noise traders always keep watching the price movements of their share and keep listening to other aspects of noise in the market, their trades can often have a short-term effect on the market, that is, the constant buying and selling can increase the price of a particular share for a short period of time. Therefore, noise trading is an important issue in the share market that needs to be observed. 
The aim of this study is to conduct a survey and examine how respondents receive noise information and how they maximize profit from trading based on a sample survey data.

The paper is organized as follows. Section 2 provides a brief review of the extant literature on noise trading. Section 3 addresses data, survey design and details of the collected data. Section 4 presents methodological issues and analytical techniques. Section 5 presents the results and discussion of results. Section 6 presents conclusions of this study.

\section{NOISE TRADING}

Noise trading is a style of investment in the stock market where the decisions to buy and sell are made without using the fundamental data from the security issuing company that are being bought or sold. As mentioned earlier, noise traders generally make short-term trades to make profit maximum from various economic trends.

According to Black (1986), "imperfect information leads to noise trading". That means trading on the prices different from the "true value" of certain stock. Therefore, existence of noise accelerates the difference in the expectations of traders and possibility to trade. He and Modest (1995) pointed out that information traders trade actively only in case of arbitrage opportunity. They take opposite positions and therefore lead market back to fundamental values of stocks. DeLong et al. (1990) support the idea that "noise traders" could significantly drive away asset prices from "fundamental values". But they come to conclusion that "smart" traders could take the same position as "noise traders" and drive market even further away from the true values if there is a very strong pressure of "noise traders" on the market.

Recent theoretical development captures such type of noise by modeling the market dynamics. Macmillan (2003) considered smooth transition model and allowed noise into account when modeling the U.K. stock index. Terasvirta $(1994,1998)$ mentioned that smooth transition regressions can capture differences in a behavior due to changes in a variable-indicator which is the noise trading mechanism.

DeLong et al. (1990) formulated a theoretical model that exhibit the effect the noise traders' participation in financial markets and explained their misperceptions regarding expected returns and volatility.

Numbers of studies are now available in the literature regarding investor behavior in the stock market. (See, e.g., Lusardi and Mitchell, 2007; Bergstresser, Chalmers, and Tufano, 2009; Bhattacharya et al., 2012; Inderst and Ottaviani, 2012a, 2012b; Mullainathan, NÖth, and Schoar, 2012; Christoffersen, Evans, and Musto, 2013; Chalmers and Reuter, 2015; Foerster et al., 2015, Gennaioli, Shleifer, and Vishny, 2015; Khan, 2011 and Von Gaudecker, 2015.)

In this study I would like to observe the opinion of the market practitioner regarding noise trading and assess the effect of noise trading on profit.

\section{Data AND Details}

To successfully conduct the study I purposively selected two divisional cities (Dhaka, the capital city and Rajshahi) of Bangladesh and collected opinions of 200 respondents from different buying housed from these two cities over a numbers of open and closed ended questions. Main reason for limiting respondent number to 200 is that respondents were not interested to respond during survey period. Some of them felt fearing to give information and numbers of investors are not able to understand the meaning of several 
stock market related questions, therefore, the felt heisted to answer. I finally depend on Sultana et al. (2016) where they conducted a research based on only 100 respondents opinion from Lanka Bangla Securities Limited.

Table 1: Respondents' economic and demographic characteristics

\begin{tabular}{|c|c|c|c|c|c|c|c|}
\hline \multicolumn{2}{|c|}{ Variables } & Mean & \begin{tabular}{|l|} 
St. Deviation \\
\end{tabular} & Skewness & Kurtosis & Minimum & Maximum \\
\hline \multirow{2}{*}{$\begin{array}{l}\text { Monthly } \\
\text { Income }\end{array}$} & Before Investment & 20031.00 & 12384.88 & 1.28 & 1.46 & 2000.00 & 60000.00 \\
\hline & After Investment & 23892.00 & 14044.25 & 1.47 & 3.05 & 1000.00 & 80000.00 \\
\hline & Respondents' Age & 40.46 & 11.29 & 0.61 & -0.21 & 22 & 70.00 \\
\hline & ff Family Members & $4.71 \approx 5$ & 1.80 & 0.95 & 1.10 & 1.00 & 12.00 \\
\hline
\end{tabular}

We observe monthly average income before investment to stock market as 20,031.00 TK with large standard deviation 12384.88 which becomes $23,892.00$ TK after investment with standard deviation 14044.25. The maximum income observed before investment $60,000.00$ TK and minimum 2000.00 TK respectively and 1,000.00 TK and 80,000.00TK after investment respectively (the minimum income holder respondents either hide their incomes or misunderstood what monthly income mean. They have been asked repeatedly about the income level but results were same). Though we are not interested about the underling distribution of monthly income but the skewness is 1.28 and kurtosis is 1.46 before investment and after investment these becomes 1.47 and 3.48 respectively which seems normally distributed.

The mean age of the respondents observed 40.46 years with standard deviation 11.29 over the range 22 to 70 years. The average no of family members observed 5 with standard deviation 1.80 .

Therefore, respondents are of different ages, different family structures with different economic status. Their opinions should be significantly independent.

Table 2: Respondents' educational and residential status

\begin{tabular}{|lccccc|}
\hline & \multicolumn{3}{c|}{ Respondents' resident } & \multicolumn{2}{c|}{ Respondents' education } \\
\cline { 2 - 6 } & Union & Thana/District town & City Corporation & Graduate & Up to secondary \\
\hline Number & 4 & 11 & 185 & 43 & 157 \\
\hline Percentage & 2.0 & 5.5 & 92.5 & 78.5 & 21.5 \\
\hline
\end{tabular}

In the case of educational qualification, I observed $78.5 \%$ investors are graduated and $21.5 \%$ are upto secondary level. $92.5 \%$ respondents in my sample live in the city corporation area, $5.5 \%$ are in Thana and District level and only $2 \%$ live in the union level. Now a days, due to the urbanization, peoples keep moving to urban area, hence, I found maximum respondents live in the city area.

From Table 3 we observe that $42.0 \%$ respondents receive noise information and $9 \%$ respondents strongly believe that information. 55\% respondents sometimes rely on that information. Respondents believe that $91 \%$ investors follow that noise to purchase and cell their share. Only $2 \%$ of the investors believe that this is a very good practice and $6 \%$ believe it is good practice. $29 \%$ respondents did not comment in this regards while $41 \%$ respondents replied that it a bad practice and $22 \%$ replied it is a very bad practice, $64 \%$ respondents believe that noise is responsible for market sudden comprehensive market change. 
Table 3: Noise related status

\begin{tabular}{|l|c|c|c|}
\hline \multicolumn{1}{|c|}{ Attributes } & Level & Frequency & Percentage \\
\hline \multirow{2}{*}{ Get noise information } & Yes & 85 & $42.0 \%$ \\
& No & 115 & $58.0 \%$ \\
\hline \multirow{3}{*}{ How much believe noise information } & All time & 18 & $9.0 \%$ \\
& Sometime & 111 & $55.0 \%$ \\
& Not at all & 71 & $36.0 \%$ \\
\hline \multirow{2}{*}{ Purchase and sell based on noise information } & Yes & 182 & $91.0 \%$ \\
& No & 18 & $9.0 \%$ \\
\hline \multirow{2}{*}{ Respondents' evaluation of noise trading } & Very good & 4 & $2.0 \%$ \\
& Good & 12 & $6.0 \%$ \\
& No comments & 59 & $29.0 \%$ \\
& Bad & 82 & $41.0 \%$ \\
Does noise trading responsible for sudden & Very bad & 43 & $22.0 \%$ \\
comprehensive market change & Yes & 128 & $64.0 \%$ \\
& No & 72 & $36.0 \%$ \\
\hline
\end{tabular}

\section{METHODS}

Since the aim of this paper is to investigate the respondent's opinion about profit from noise trading and how they receive noise information while trading, therefore, the study explores the interrelationships between attributes through contingency analysis and to measure the relationship through a logistic regression analysis.

The interrelationship between attributes is explored through the $\chi^{2}$ test where the statistic is

$\chi^{2}=\sum_{i j} O_{i j}^{2} / E_{i j}-N$

That follows chi-square distribution with $(r-1)(c-1)$ degree of freedom under usual notations.

The logistic regression model for qualitative (dichotomous) dependent variable can be written as

$E(y)=\beta_{0}+\beta_{1} x_{1}+\beta_{2} x_{2}+\cdots \cdots \cdots+\beta_{k} x_{k}$

That can be written as

$\ln \left(\frac{p}{1-p}\right)=\beta_{0}+\beta_{1} x_{1}+\beta_{2} x_{2}+\cdots \cdots \cdots+\beta_{k} x_{k}$

Where $p=\frac{e^{\left(\beta_{0}+\beta_{1} x_{1}+\beta_{2} x_{2}+\cdots \cdots \cdots+\beta_{k} x_{k}\right)}}{1+e^{\left(\beta_{0}+\beta_{1} x_{1}+\beta_{2} x_{2}+\cdots \cdots \cdots+\beta_{k} x_{k}\right)}}$, This function of the linear predictor is known as the logistic function with $y$ is the dependent dichotomous variable and $x$ 's are independent variables. Since I have purposively collected the respondents' opinions, therefore, logistic regression is the best technique to analyze collected data as logistic regression model does not require any distributional assumption. 


\section{RESULTS AND DISCUSSION}

Table 4: Getting advance/noise information and associated factors

\begin{tabular}{|c|c|c|c|c|c|}
\hline \multirow[t]{2}{*}{ Attributes } & \multirow{2}{*}{\multicolumn{2}{|c|}{ Attributes }} & \multicolumn{3}{|c|}{$\chi^{2}$ Values } \\
\hline & & & Overall & Dhaka & Rajshahi \\
\hline \multirow{12}{*}{ 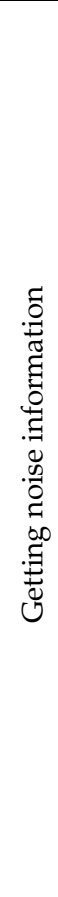 } & \multirow{2}{*}{ Monthly income } & before investment & $\begin{array}{c}6.705 \\
(\mathrm{df}=1, \rho=0.010)\end{array}$ & $\begin{array}{c}2.007 \\
(\mathrm{df}=1, \mathrm{p}=0.157)\end{array}$ & $\begin{array}{c}4.773 \\
(\mathrm{df}=1, \mathrm{p}=0.029)\end{array}$ \\
\hline & & after investment & $\begin{array}{c}3.359 \\
(\mathrm{df}=1, \mathrm{p}=0.067)\end{array}$ & $\begin{array}{c}2.010 \\
(\mathrm{df}=1, \mathrm{p}=0.156)\end{array}$ & $\begin{array}{c}1.463 \\
(\mathrm{df}=1, \mathrm{p}=0.226)\end{array}$ \\
\hline & \multirow{2}{*}{ Bank account } & before investment & $\begin{array}{c}1.360 \\
(\mathrm{df}=1, \rho=0.244)\end{array}$ & $\begin{array}{c}0.779 \\
(\mathrm{df}=1, \mathrm{p}=0.377)\end{array}$ & $\begin{array}{c}1.432 \\
(\mathrm{df}=1, \mathrm{p}=0.231)\end{array}$ \\
\hline & & after investment & $\begin{array}{c}0.892 \\
(\mathrm{df}=1, \mathrm{p}=0.345)\end{array}$ & $\begin{array}{c}5.460 \\
(\mathrm{df}=1, \mathrm{p}=0.019)\end{array}$ & $\begin{array}{c}0.340 \\
(\mathrm{df}=1, \mathrm{p}=0.560)\end{array}$ \\
\hline & \multirow{2}{*}{ Build house } & before investment & $\begin{array}{c}5.281 \\
(\mathrm{df}=1, \rho=0.022)\end{array}$ & $\begin{array}{c}2.481 \\
(\mathrm{df}=1, \mathrm{p}=0.115)\end{array}$ & $\begin{array}{c}3.182 \\
(\mathrm{df}=1, \mathrm{p}=0.074)\end{array}$ \\
\hline & & after investment & $\begin{array}{c}0.040 \\
(\mathrm{df}=1, \mathrm{p}=0.841)\end{array}$ & $\begin{array}{c}0.142 \\
(\mathrm{df}=1, \mathrm{p}=0.706)\end{array}$ & $\begin{array}{c}0.319 \\
(\mathrm{df}=1, \mathrm{p}=0.572)\end{array}$ \\
\hline & \multirow{2}{*}{ Land purchase } & before investment & $\begin{array}{c}1.726 \\
(\mathrm{df}=1, \rho=0.189)\end{array}$ & $\begin{array}{c}0.317 \\
(\mathrm{df}=1, \mathrm{p}=0.574)\end{array}$ & $\begin{array}{c}1.266 \\
(\mathrm{df}=1, \mathrm{p}=0.261)\end{array}$ \\
\hline & & after investment & $\begin{array}{c}5.333 \\
(\mathrm{df}=1, \mathrm{p}=0.021)\end{array}$ & $\begin{array}{c}2.750 \\
(\mathrm{df}=1, \mathrm{p}=0.097)\end{array}$ & $\begin{array}{c}2.831 \\
(\mathrm{df}=1, \mathrm{p}=0.092)\end{array}$ \\
\hline & \multirow{2}{*}{ Buy flat/apartment } & before investment & $\begin{array}{c}0.176 \\
(\mathrm{df}=1, \rho=0.675)\end{array}$ & $\begin{array}{c}0.779 \\
(\mathrm{df}=1, \mathrm{p}=0.377)\end{array}$ & $\begin{array}{c}1.554 \\
(\mathrm{df}=1, \mathrm{p}=0.213)\end{array}$ \\
\hline & & after investment & $\begin{array}{c}2.128 \\
(\mathrm{df}=1, \mathrm{p}=0.145)\end{array}$ & $\begin{array}{c}4.612 \\
(\mathrm{df}=1, \mathrm{p}=0.032)\end{array}$ & $\begin{array}{c}9.188 \\
(\mathrm{df}=1, \mathrm{p}=0.002)\end{array}$ \\
\hline & \multirow{2}{*}{$\begin{array}{l}\text { Children's edu } \\
\text { cationalexpenses } \\
\text { deficiency }\end{array}$} & before investment & $\begin{array}{c}12.236 \\
(\mathrm{df}=8, \rho=0.141)\end{array}$ & $\begin{array}{c}21.684 \\
(\mathrm{df}=7, \mathrm{p}=0.003)\end{array}$ & $\begin{array}{c}11.999 \\
(\mathrm{df}=8, \mathrm{p}=0.151)\end{array}$ \\
\hline & & after investment & $\begin{array}{c}24.453 \\
(\mathrm{df}=8, \mathrm{p}=0.002)\end{array}$ & $\begin{array}{c}11.839 \\
(\mathrm{df}=8, \mathrm{p}=0.159)\end{array}$ & $\begin{array}{c}19.191 \\
(\mathrm{df}=8, \mathrm{p}=0.014)\end{array}$ \\
\hline
\end{tabular}

From the above table we observe that getting noise information significantly associated with respondents' monthly income (before \& after), build a house before invest, purchase land after investment, expense of children education after investment in stock market and no significant association observed for bank account before and after investment, build a house after investment, purchased the land before, buy a flat before and after investment, expense of children education before investment.

When the regions of investment come into account, we observed for the attribute advance information about either the value of share will increase or decrease is significantly associated with income and build a house before investment, purchased land, flat and expense of children education in Rajshahi but not in Dhaka.

Inverse association observed for the bank account, purchased land and flat after investment and expense of children education before are significantly associated advance information about either the value of share will increase or decrease in Dhaka but not in Rajshahi.

From the table 5we observe that opinion on the ways to get noise information significantly associated with respondents' age, educational qualification and no significant association observed for profession, family member, and residence.

When the regions of investment come into account, we observed that ways of getting noise information significantly associated with family member, educational qualification in Rajshahi but not in Dhaka and no significant association observed for profession, age, residence. 
Table 5: Association between ways to get noise information with respondents' sociodemographic fators

\begin{tabular}{|l|c|cc|}
\hline \multirow{2}{*}{ Attributes } & \multicolumn{3}{c|}{$\chi^{2}$ Values } \\
\cline { 2 - 5 } & Overall & Dhaka & Rajshahi \\
\hline \multirow{2}{*}{ Respondents' profession } & $\begin{array}{c}3.613 \\
(\mathrm{df}=2, \mathrm{p}=0.164)\end{array}$ & $\begin{array}{c}2.357 \\
(\mathrm{df}=2, \mathrm{p}=0.308)\end{array}$ & $\begin{array}{c}2.167 \\
(\mathrm{df}=2, \mathrm{p}=0.338)\end{array}$ \\
\cline { 2 - 5 } & $\begin{array}{c}10.429 \\
(\mathrm{df}=1, \mathrm{p}=0.001)\end{array}$ & $\begin{array}{c}15.467 \\
(\mathrm{df}=1, \mathrm{p}=0.000)\end{array}$ & $\begin{array}{c}0.557 \\
(\mathrm{df}=1, \mathrm{p}=0.456)\end{array}$ \\
\hline & $\begin{array}{c}2.604 \\
(\mathrm{df}=1, \mathrm{p}=0.107)\end{array}$ & $\begin{array}{c}1.799 \\
(\mathrm{df}=1, \mathrm{p}=0.180)\end{array}$ & $\begin{array}{c}10.078 \\
(\mathrm{df}=1, \mathrm{p}=0.002)\end{array}$ \\
\hline & $\begin{array}{c}22.13 \\
(\mathrm{df}=8, \mathrm{p}=0.005)\end{array}$ & $\begin{array}{c}15.509 \\
(\mathrm{df}=6, \mathrm{p}=0.017)\end{array}$ & $\begin{array}{c}13.478 \\
(\mathrm{df}=8, \mathrm{p}=0.096)\end{array}$ \\
\hline & $\begin{array}{c}3.004 \\
(\mathrm{df}=4, \mathrm{p}=0.557)\end{array}$ & $\begin{array}{c}6.962 \\
(\mathrm{df}=4, \mathrm{p}=0.138)\end{array}$ & $\begin{array}{c}3.493 \\
(\mathrm{df}=4, \mathrm{p}=0.479)\end{array}$ \\
\hline
\end{tabular}

Inverse association observed for the age, educational qualification are significantly associated with advance information about either the value of share will increase or decrease in Dhaka but not in Rajshahi and no significant association observed for profession, family member, residence.

Table 6: Association between thinking about the way to get this kind of information and especially investment information

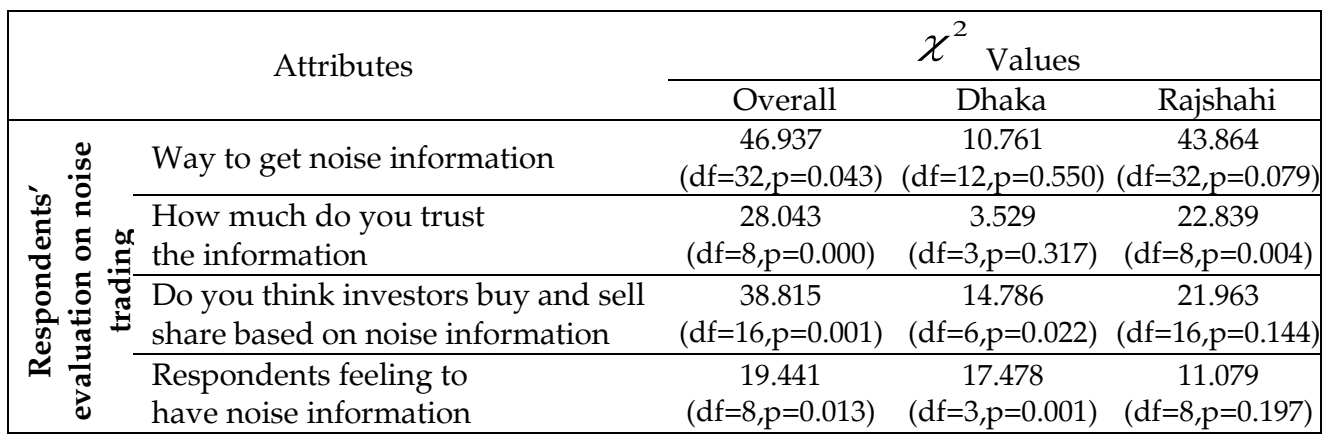

From the above table we observe that respondents' evaluation regarding noise trading (very good, good, no comment, bad, very bad) significantly associated with respondents getting noise information, respondents trust this information and they buy and sell share based on this noise information and their feeling (very good, good, no comment, bad, very bad) to have noise information.

When the regions of investment come into account, we observed for respondents' evaluation regarding noise trading significantly associated with respondents getting noise information, respondents' trust this information in Rajshahi but not in Dhaka and no significant association observed for respondents buy and sell their share based on noise information and their feelings regarding noise trading.

Inverse association observed for Dhaka based respondents. That is respondents' evaluation regarding noise trading significantly associated with respondents buy and sell their share based on noise information and their feelings regarding noise trading but no significant association observed for respondents getting noise information and their trust on noise information. 
Table 7: Logistic regression

\begin{tabular}{|l|c|c|c|}
\hline \multicolumn{1}{|c|}{ Characteristic } & Coefficient & $p$-value & Odds ratio \\
\hline Occupation & -0.080 & 0.538 & 0.923 \\
\hline Age & $\mathbf{0 . 3 1 2}$ & $\mathbf{0 . 0 0 0}$ & 1.366 \\
\hline No. of family members & $\mathbf{- 0 . 9 7 9}$ & $\mathbf{0 . 0 0 7}$ & 0.376 \\
\hline Educational Status & $\mathbf{- 1 . 8 9 5}$ & $\mathbf{0 . 0 0 0}$ & 0.150 \\
\hline Residential area & -0.402 & 0.427 & 0.669 \\
\hline Income before investment & $\mathbf{0 . 3 2 9}$ & $\mathbf{0 . 0 2 9}$ & 1.390 \\
\hline Income after investments & $\mathbf{- 0 . 7 2 3}$ & $\mathbf{0 . 0 0 0}$ & 0.485 \\
\hline
\end{tabular}

Table 7 shows the logistic regression analysis results on "Do you get noise information" as the dependent variable and all other attributes as mentioned in the table are independent variable.

We observe negative significant impact of respondent's education, no of respondent's family members, and income after investment on the getting noise information. Significant positive influence observed for respondents' age and income before investment.

The positive influence of age and income before investment may occur due to the experience cumulated with age and need of money at income level before investment.

\section{CONCLUSION}

In Bangladesh a rapid crash of the share market in 2011 had sparked violent protests from the investors. It was the biggest one-day fall in the Bangladesh stock market's 55-years history. It is estimated that over 3.5 million (35 lac) people, many of them small-scale individual investors had lost their money because of the sharp plunge in share prices.

Basically, I analyze the noise trading activities involved in the stock market, respondents' economic status and ways of getting noise information and ensure trading based on these noises.

However, we observed a completely different scenario between Dhaka and Rajshahi. The reason may be the income level and living standard of the respondents. When we observed association in the regional level, we experienced that advance information about either the value of share will increase or decrease is significantly associated with family member, educational qualification in Rajshahi but not in Dhaka

The most remarkable thing is, $42 \%$ of out respondents can have noise information. $91 \%$ respondents believe that investors are buying and selling their share based on this noise. These types of conditions will definitely make market more volatile. It is now well observed that the volatility and return are negatively related. Therefore, for the betterment of our stock market, the investors and the authority should take great care of such noise trading. Otherwise, the investor will be demoralized and the market will be more volatile and returns will be negative. The entire economic situation may be unstable for long period.

One more thing is being observed from the study that the majority of the respondents improved their economic status after investment. Respondents with less or minimum information and knowledge regarding stock market activity may become loser. However, all the investors more or less become unsatisfied regarding their profit from the stock market. 


\section{REFERENCE}

Bergstresser, D., Chalmers, J.M.R. and Tufano, P. (2009),"Assessing the costs and benefits of brokers in the mutual fund industry", Review of Financial Studies, Vol.22, 4129-4156.

Bhattacharya, U., Hackethal, A., Kaesler,S., Loos, B. and Meyer,S. (2012), "Is unbiased financial advice to retail investors sufficient? Answers from a large field study", Review of Financial Studies, Vol.25, 975-1032.

Black, F. (1986), "Noise", The Journal of Finance, Vol. 41 (3), 528-534

Chalmers, J. and Jonathan Reuter, J. (2015), "Is conflicted investment advice better than no advice?" Working Paper.

Christoffersen, S., Evans, R., and Musto, D. (2013), "What do consumers' fund flows maximize? Evidence from their brokers' incentives", Journal of Finance,Vol.68, 201-235.

DeLong, J.B.S., A. Summers, L.H., and Waldmann, R.J. (1990), “Noise trader risk in financial markets",.Journal of Political Economy, Vol. 98(4), 703-738.

Foerster, S., Linnainmaa, J., Melzer, B. and Previtero, A. (2015), “Retail financial advice: Does one size fit all?" Forthcoming: Journal of Finance.

Gennaioli, N., Shleifer, A. and Vishny, R. (2015), "Money doctors", Journal of Finance, Vol.70, 91-114.

He, H. and Modest, D. (1995), "Market Frictions and Consumption-Based Asset Pricing", Journal of Political Economy, Vol. 103, 94-117

Inderst, R. and Ottaviani,M. (2012a), "Financial advice", Journal of Economic Literature, Vol.50, 494-512.

Inderst, R. and Ottaviani,M. (2012b), "How (not) to pay for advice: A framework for consumer financial protection", Journal of Financial Economics, Vol.105, 393-41

Khan, M.A.I. (2011), “Financial Volatility Forecasting by Nonlinear Support Vector Machine Heterogeneous Autoregressive Model: Evidence from Nikkei 225 Stock Index", International Journal of Economics and Finance, Vol.3(4), 138.

Kyle, Albert.S.(1985), "Continuous Auctions and Insider Trading", Econometrica, Vol. 53(6), 13151336.

Lusardi, A, and Mitchell, O.S. (2007), "Baby boomer retirement security: The roles of planning, financial literacy, and housing wealth", Journal of Monetary Economics, Vol.54, 205-224.

MacMillan, D.G. (2003), "Non-linear predictability of stock market returns", Oxford Bulletin of Economics and Statistics, Vol. 65, 557-573.

Mullainathan, S., NÖth,M. and Schoar, A. (2012), "The market for financial advice: An audit study", Working Paper.

Sultana, I., Hossain, M.E. and Uddin, M. (2016), "Investing the Present Capital Market Crisis and Recovery Stategies in Bangladesh", Asian Journal of Management Science E Education, Vol. 5(1)

Teräsvirta, T. (1994), "Specification, estimation, and evaluation of smooth transition autoregressive models", Journal of the American Statistical Association, Vol.89, 208-218.

Teräsvirta, T. (1998), "Modeling economic relationships with smooth transition regressions", in A. Ullah and D. E. Giles (eds), Handbook of Applied Economic Statistics, Dekker, New York, 507-552.

VikashRamiah, XiaomingXu, and Imad A. Moosa (2015), “Neoclassical finance, behavioral finance and noise traders: A review and assessment of the literature", International Review of Financial Analysis, Vol 41, 89-100

Von Gaudecker, and Hans M., (2015), "How does household portfolio diversification vary with financial literacy and financial advice?" Journal of Finance, Vol.70, 489-507. 